\title{
Healthy Life Style Status of Wolkite University Academic Staffs Vis-Ä-Vis Second-Generation University Academic Staffs of Center Ethiopia
}

\author{
Bizuneh Shamebo Shebo ${ }^{1} \quad$ Abdulaziz Musema Hassen ${ }^{1} \quad$ Mohammed Derese Biru $^{2 *}$ \\ 1.Department of Sport Science, College of Natural and Computational Sciences, \\ Wolkite University, Wolkite, Ethiopia \\ 2.Department of Statistics, College of Natural and Computational Sciences, \\ Wolkite University, Wolkite, Ethiopia
}

\begin{abstract}
Background: University staffs play a vital role in producing an intellectual generation of one's country. The healthy life status of instructors may have both positive or negative impacts on services that they provide to students and on the quality of education. Therefore, this study aimed to examine a healthy lifestyle status of wolkite university academic staff as compared to second-generation university.

Methods: This cross-sectional study was conducted on University instructors from three different Universities of Debre Birahn, Wolkite and Wolita Sodo Universities found in Ethiopia. A stratified random sampling technique was employed for selected study participants. During data collection methods demographic variables and healthpromoting lifestyle profile 2 standardized questionnaires were used. Each item's expression was scored on a scale of 1 to 4. Internal consistency (Cronbach's Alpha) of this tool was in acceptable interval $\alpha=0.868$. Finally, the data were analyzed by using descriptive statistics and inferential statistical tests like the Chi-Square test of association, Independent T-test and Analysis of variance.

Results: According to the results, the descriptive analysis of subscales of health-promoting lifestyle profile 2 for both gender male and female showed that the highest mean was recorded for health responsibility subscale whereas the lowest mean belongs to the subscale of physical activity.

The mean health-promoting lifestyle among three universities Wolkite University was lower than other universities in terms of the subscale of physical activity and Wolita Sodo university was higher than other universities in terms of the subscale of health responsibility. There is no significant mean difference between universities.

The independent T-test result shows that there's a significant mean difference between male and female instructors in subscales of physical activity and Nutrition.

Conclusions

This study found that the Nutrition and Physical activity subscales of health-promoting lifestyle was low. The healthy promoting lifestyle of staff members in the three universities had no significant mean different. Staff should have the habit of scheduled physical activities to keep safe their healthy lifestyle.
\end{abstract}

Keywords: Health-promoting Lifestyle Status, demographic characteristics, Instructors

DOI: $10.7176 / \mathrm{JHMN} / 67-02$

Publication date:October $31^{\text {st }} 2019$

\section{Background}

Now a day's all nations need to have productive citizens along with their remarkable development in all aspects. The issue of healthy lifestyle status of an individual is one of the fundamental rights of every human being without distinction of race, religion, political belief, economic or social condition. Universities are dedicated to the values of a healthy lifestyle for all, making life easier and continuous growth can be an incredible asset to their staff and students, to the communities in which they are originated and to the whole community where their students and trainees will ultimately be applied professional knowledge and skills [1].

The practice of healthy lifestyles of individuals should start from daily habits and the living environment. Leading a healthy lifestyle will depend on a healthy environment, which guarantees peoples to be free from illness. Moreover, creating a living environment, which is safe, satisfying, enjoyable and motivating, contributes to healthier and happier living. Even though a healthy lifestyle individual is strongly affected by a variety of factors. According to several studies have overwhelmingly shown that individuals who care about their healthy life status leads to a noticeable reduction in overall mortality, heart disease, diabetes, hypertension, stroke, congestive heart failure, and other communicable disease and live a longer healthier [2].

Healthy lifestyle contributed to various positive benefits throughout the life span of peoples living in various corner of the world, however, various researchers stated poor lifestyle as the susceptible cause of mortality in the U.S. and approximately 70 percent of all the physical and mental diseases are related to this problem [3]. Besides, controlling risk factors in lifestyle and healthy habits such as poor nutrition, physical inactivity, smoking, alcohol consumption, and drug use almost can reduce early deaths by half [4]. Furthermore, in many developing countries 
in Africa, the problem related to poor lifestyle even become worse. Health promotion should, therefore, start from daily habits and creating a living environment, which is safe, satisfying, enjoyable and interesting, contributes to healthier and happier living.

Thus, When the staff improves their healthy lifestyle status based on the standardized healthy lifestyle principle, this also has a direct impact on the quality of life and improves the staffs' participation in their day-today activity.

Moreover, the researcher observed many problems regarding the healthy lifestyle of peoples working at Wolkite University. By applying the Health Promotion lifestyle 2 models proposed in the early 1980s as extracting tools of important information regarding factors determining of a healthy lifestyle [5].Thus, the purpose of this study was to find out the status of Wolkite University academic and administrative staffs' lifestyle against healthy lifestyle principles by comparing with some selected second-Generation University found in the country.

\section{Method}

A cross-sectional study was conducted on University instructors from three different Universities 190,178 and 179 of Debre Birahn, Wolkite and Wolita Sodo respectively found in the Republic of Ethiopia. To select representative samples among the target population the researchers used a stratified simple random sampling technique. The list of all instructors obtained from each university human resource office, and then they will employ lottery methods to select the participants from the population. This method will give all the participants to have equal chances to be selected and also this method avoids personal bias.

A sample size of 547 was determined using a single population proportion with the assumption that the proportion of healthy lifestyle $50 \%$, a margin of error $4 \%$ and Type I error of $5 \%$.

A structured questionnaire was used for data collection the questionnaire included demographic characteristics and health-promoting lifestyle profile 2 consisting of 52 items with 6 subscales of Nutrition, Physical Activity, Spiritual Growth, Health Responsibility, Interpersonal Relations, and Stress Management.

To keep the weight of items expression for each item subscale scores mean were used. Each item expression was scored on a scale of 1 to 4 with a list of categories Never $=1$, Sometimes $=2$, Usually $=3$, and Always $=4$. The psychometrically evaluated and internal consistency (Cronbach's Alpha) of this tool was in acceptable interval $\alpha$ $=0.868$. Finally, the data were analyzed by using descriptive statistics likes Mean, Standard Deviation and Percentages, as well as inferential statistical tests like Chi-Square association, Independent T-test and Analysis of variance, were used.

\section{Result}

In this study, a total of 547 university instructors were considered from three different universities. The result in figure 1 revealed that $34.73 \%$ of them were from Wolkite University and the rest $32.72 \%$ and $32.54 \%$ were from Wolita Sodo University and Debre Brahan University respectively.

Table 1 reveals that the highest proportion of young age group being $26-30$-year olds $63.2 \%$ of respondents were found in Wolkite University and followed by Wolaita Sodo University (52.5\%) and Debre Brahan University $(41 \%)$. where a proportion of elder age group greater than 35-year olds representing the largest group was found in Debre Brahan University (16.3\%). followed by and Wolkite University $(8.4 \%)$ and Wolaita Sodo University $(6.7 \%)$

The largest share of first-degree instructors $(25.1 \%)$ of belonged to Wolaita Sodo University, the highest proportion of those with a second degree were in Wolkite University (79.5\%) and third-degree Level qualifications were higher in Debre Brahan University (10.7\%)

From table 1 when we compare work experience of respondents in the three universities the highest proportion of work experience in between 2-5 years was recorded at Wolkite University $(41.6 \%)$ and followed by Debre Brahan University (37.1\%). Whereas the largest proportion of Work experience in between 5-10 years was observed in Wolaita Sodo University.

The majority of respondents were with greater than net 10,000-birr monthly income $(54.5 \%, 47.5 \%)$ in Debre Brahan and Wolaita Sodo University respectively except Wolkite University were (48.9\%) net 5,000-10,000-birr monthly income.

Based on the Chi-square test, all demographic variables listed in table 1 like Age, Educational Status, Work experience, and Monthly Income were significantly associated with three categories of the university.

To decide the status of health-promoting subscales and the related components, scores of instructor of three universities were separated into four break accordingly $75.4 \%$ of Wolita Soda University instructors perceived health-promoting behaviors at fair level of Nutrition, $60.1 \%$ and $60.0 \%$ Debrebrahan University instructors conscious of health-promoting behaviors physical activity and health responsibility at fair and high level respectively, and Wolkite University instructors conscious of health-promoting behaviors stress management and interpersonal relations were perceived by $59.5 \%$ and 49.5 respectively at high level.

Based on table 2 results, there was a significant association between physical activity and three university 
categories, on the other hand, no significant association between Nutrition, Stress management, interpersonal relations, health responsibility with the three groups of universities at $\alpha=0.05$ significance level.

Based on table 3, the mean of female instructors in subscales of nutrition, stress management, interpersonal relationship, health responsibility, spiritual growth and total scale of the health-promoting way of life profile 2 used to be greater than male students. Within the sub-scale of physical activity, the mean of female instructors was lower than males.

The independent T-test result shows that there's a noteworthy distinction between male and female instructors in subscales of physical activity and Nutrition. According to independent T-test results, there's a not statistically significant difference between male and female instructors of rest subscales at $\alpha=0.05$ significance level.

The mean of physical activity, nutrition and health responsibility subscales in Wolaita Sodo University instructors were higher than the other university, instructor of Wolkite University had high mean of Stress Management and Interpersonal Relations subscale of healthy lifestyle while compared with rest university and Spiritual Growth of subscale of healthy lifestyle was higher in Debre Brahan University instructors.

As regards analysis of variance test point out that there is no statistically significant mean difference between the three University instructors in terms of Physical Activity, Nutrition, Stress Management, Interpersonal Relations, Health Responsibility and Spiritual Growth subscales of a healthy lifestyle at $\alpha=0.05$ significance level (Table 4).

\section{Discussion}

This study analyzed the health-promoting lifestyles of three different university instructors in the southern center of Ethiopia. Based on the study results, mean and standard deviation of health-promoting lifestyle status of university instructors was $2.71 \pm 0.36$.while we compare with different findings, it is greater than of the mean and standard deviation of health-promoting lifestyles done in Tehran city[6,7] whereas the mean and standard deviation of health-promoting lifestyles our finding was less than the finding's reported in Mahidol University [8]. This might happen due to the difference in socio-economic, geographical location and living standards of the citizens. In the current study, physical activity subscale identified as a statistically associated variable with healthpromoting lifestyle among three universities and the mean of health-promoting lifestyle university in terms of the subscale of physical activity was lower than others the other subscale. This result was consistent with the findings $[7,9,10]$ and it may raise from less devotion for physical activities and constraints of important facilities for physical activities.

In this study mean of female instructors in subscales of nutrition, stress management, interpersonal relationship, health responsibility, spiritual growth and total scale of the health-promoting way of life profile 2 used to be greater than male staffs. The mean of health-promoting lifestyle female instructors was lower than male instructors in terms of the subscale of physical activity. There was a statistical significance of the mean difference between male and female instructors. Our finding was opposed to the result conducted on teachers in Turkey University and another study revealed that there was a statistically significant difference between male and female teachers in sub-dimensions of physical activity and other sub-dimensions [12-15].

In the present study, subscales of Stress Management and Health Responsibility of instructor's had high scores the rest subscales of Health-Promoting Lifestyle Profile 2 had fair scores except sub-dimensions of physical activity. The result is in line with other findings $[8,15]$

Moreover, there was a significant association between demographic variables like Age, Educational Status, Work experience and Monthly Income with the Health-Promoting Lifestyle of three university categories. Our result was similar to other findings [15-18]

\section{Conclusions}

Based on the study we conclude that, The Nutrition and Physical activity subscales of healthy promoting lifestyle was low. Healthy promoting lifestyle of staff members in the three universities had no significant mean different. Staffs should have the habit of scheduled physical activities in order to keep safe their healthy lifestyle. The universities also should have resolved every constraint related to facilities for staff. The findings of this study may support University instructors, university leaders ship and policymakers for strategic plan and policy implantations for promoting the health life status level of University instructors.

Competing interest

The authors declare that they have no competing interests.

\section{Reference}

1. World Health Organization Regional Office for Europe. Copenhagen Health Promoting Universities. Concept, experience and framework for action. ISBN 9289012854

2. Pakholok, O. (2013). The Idea of Healthy Lifestyle and its Transformation Into Health-Oriented Lifestyle in Contemporary Society. https://doi.org/10.1177/2158244013500281 
3. Monahan F, Sands JK, Neighbors M, Marek JF, Green CJ. Phipps' medical-surgical nursing: Health and illness perspectives. 7th ed. St. Louis: Mosby; 2003.

4. Delaun SC, Ladner PK. Fundamental of nursing standard and practice. Albany: Delmar; 1998.

5. Walker, S. N. , \& Hill-Polerecky, D. M. (1996). Psychometric evaluation of the Health Promoting lifestyle profile 2. Unpublished manuscript, University of Nebraska Medical Centre.

6. McElligott, D., Capitulo, K. L., Morris, D. L., \& Click, E. R. (2010). The effect of a holistic program on health promoting behaviors in hospital registered nurses. Journal of Holistic Nursing, 28(3), 175-183

7. Meimanat H, Tahereh A., Mohammad H., Ali E. \& Hossein R, 2013. Health-Promoting Behaviors and Their Association with Certain Demographic Characteristics of Nursing Students of Tehran City. Global Journal of Health Science; Vol. 7, No. 2; 2015 ISSN 1916-9736 E-ISSN 1916-9744

8. Hong, F. J., Sermesri, S., \& Keiwkarnka, B. (2007). Health-promoting lifestyles of nursing students in Mahidol University. Journal of Public Health and Development, 5(1), 27-40.

9. Eshah, N. F. (2011). Lifestyle and health promoting behaviours in Jordanian subjects without prior history of coronary heart disease. International Journal of Nursing Practice, 17, 27-35.

10. Motlaq, Z., Mazloomi Mahmoodabad, S. S., \& Momayyezi, M. (2010). Health Promotion Behavior's in Students. Zahedan Journal for Medical Sciences Researches (Tabibe Sharq), 13, 29- 34 (In Persian).

11. İlhan N, Batmaz M, Akhan LU. Üniversite öğrencilerinin sağlıklı yaşam biçimi davranışlarının incelenmesi. II. Ulusal Halk Sağlığı Kongresi. Denizli, 2007.

12. Kafkas ME, Şahin Kafkas A, Acet M. Beden eğitimi öğretmenlerinin sağlıklı yaşam biçimi davranış düzeylerinin incelenmesi, 2012

13. Koçoğlu D, Konya kent merkezinde sağlıklı yaşam biçimi davranışları ve yasam kalitesinde sağlıkta sosyoekonomik eşitsizlikler, Selçuk Üniversitesi Sağlık Bilimleri Enstitüsü Hemşirelik Anabilim Dalı Yüksek Lisans Tezi, 2006.

14. Kadir T. and Ugur A. 2017. Examining healthy lifestyle behaviors of academic personnel working at a Gaziantep University. Turkish Journal of Sport and Exercise. http://dergipark.gov.tr/tsed Volume: 19 - Issue: 1 - Pages: 7-10

15. Soleimani, A., Taghlili, F., \& Rasouli, M. (2005). Health behaviors of nursing freshmen in relation to risk factors for coronary artery disease. Journal of Nursing and Midwifery, Hamedan, 24(13), 22-27.

16. Ozbaşaran F, Cetinkaya AC, Gungor N. Celal Bayar Universitesi Sağlık Yuksekokulu Oğrencilerinin Sağlık Davranışları. Journal of Anatolia Nursing and Health Sciences 2004;7.

17. Deeks A, Lombard C, Michelmore J, Teede H. The effects of gender and age on health-related behaviors. BMC Public Health 2009; 9:213.

18. Demir G, Arız A. Healthy Life Style Behaviors of Migrant Women and Influencing Factors. Duzce Universitesi Sağlık Bilimleri Enstitusu Dergisi 2014; 1:1-8.

Table 1 Socio-economic and demographic variables of the respondents and Chi-Square test of Associations

\begin{tabular}{|c|c|c|c|c|c|c|c|c|}
\hline & \multicolumn{6}{|c|}{ Universities Name } & \multirow{2}{*}{$\begin{array}{l}\text { P- } \\
\text { Value }\end{array}$} \\
\hline & & \multicolumn{2}{|c|}{$\begin{array}{l}\text { Wolkite } \\
\text { University }\end{array}$} & \multicolumn{2}{|c|}{$\begin{array}{l}\text { Debre Brahan } \\
\text { University }\end{array}$} & \multicolumn{2}{|c|}{$\begin{array}{ll}\text { Wolaita } & \text { Sodo } \\
\text { University } & \end{array}$} & \\
\hline & & $\mathrm{F}$ & $\mathrm{N} \%$ & $\mathrm{~F}$ & $\mathrm{~N} \%$ & $\mathrm{~F}$ & N \% & \multirow[t]{5}{*}{$<0.000$} \\
\hline \multirow{4}{*}{ Age } & $20-25$ & 27 & $14.2 \%$ & 22 & $12.4 \%$ & 22 & $12.3 \%$ & \\
\hline & $26 .-30$ & 120 & $63.2 \%$ & 73 & $41.0 \%$ & 94 & $52.5 \%$ & \\
\hline & $31-35$ & 27 & $14.2 \%$ & 54 & $30.3 \%$ & 51 & $28.5 \%$ & \\
\hline & $>35$ & 16 & $8.4 \%$ & 29 & $16.3 \%$ & 12 & $6.7 \%$ & \\
\hline \multirow{3}{*}{$\begin{array}{l}\text { Educational } \\
\text { Status }\end{array}$} & B.A & 34 & $17.9 \%$ & 30 & $16.9 \%$ & 45 & $25.1 \%$ & \multirow[t]{3}{*}{0.003} \\
\hline & M.Sc & 151 & $79.5 \%$ & 129 & $72.5 \%$ & 126 & $70.4 \%$ & \\
\hline & PHD & 5 & $2.6 \%$ & 19 & $10.7 \%$ & 8 & $4.5 \%$ & \\
\hline \multirow{4}{*}{$\begin{array}{l}\text { Work } \\
\text { experience }\end{array}$} & $<2$ Years & 41 & $21.6 \%$ & 22 & $12.4 \%$ & 26 & $14.5 \%$ & \multirow[t]{4}{*}{0.024} \\
\hline & 2-5 Years & 79 & $41.6 \%$ & 66 & $37.1 \%$ & 62 & $34.6 \%$ & \\
\hline & 5-10Years & 56 & $29.5 \%$ & 62 & $34.8 \%$ & 70 & $39.1 \%$ & \\
\hline & $>10$ Years & 14 & $7.4 \%$ & 28 & $15.7 \%$ & 21 & $11.7 \%$ & \\
\hline \multirow{3}{*}{$\begin{array}{l}\text { Monthly } \\
\text { Income }\end{array}$} & $<5000$ Birr & 16 & $8.4 \%$ & 5 & $2.8 \%$ & 30 & $16.8 \%$ & \multirow[t]{3}{*}{$<0.000$} \\
\hline & $\begin{array}{l}5000- \\
10,000\end{array}$ & 93 & $48.9 \%$ & 76 & $42.7 \%$ & 64 & $35.8 \%$ & \\
\hline & $>10,000$ & 81 & $42.6 \%$ & 97 & $54.5 \%$ & 85 & $47.5 \%$ & \\
\hline
\end{tabular}


Table 2 Chi-Square test of Association for healthy promotion life style by university Instructors

\begin{tabular}{|c|c|c|c|c|c|c|c|c|}
\hline & \multicolumn{6}{|c|}{ Universities Name } & \multirow[t]{3}{*}{ P-value } \\
\hline & & \multicolumn{2}{|c|}{ WKU } & \multicolumn{2}{|c|}{ DBU } & \multicolumn{2}{|c|}{ WSU } & \\
\hline & & Count & $\%$ & Count & $\%$ & Count & $\%$ & \\
\hline \multirow{4}{*}{ Nutrition } & Poor & - & - & - & - & - & - & \multirow[t]{4}{*}{0.800} \\
\hline & Low & 36 & $18.9 \%$ & 30 & $16.9 \%$ & 28 & $15.6 \%$ & \\
\hline & Fair & 134 & $70.5 \%$ & 127 & $71.3 \%$ & 135 & $75.4 \%$ & \\
\hline & High & 20 & $10.5 \%$ & 21 & $11.8 \%$ & 16 & $8.9 \%$ & \\
\hline \multirow{4}{*}{ Physical activity } & Poor & - & - & - & - & - & - & \multirow[t]{4}{*}{0.011} \\
\hline & Low & 57 & $30.0 \%$ & 49 & $27.5 \%$ & 53 & $29.6 \%$ & \\
\hline & Fair & 113 & $59.5 \%$ & 107 & $60.1 \%$ & 86 & $48.0 \%$ & \\
\hline & High & 20 & $10.5 \%$ & 22 & $12.4 \%$ & 40 & $22.3 \%$ & \\
\hline \multirow{4}{*}{ Stress management } & Poor & - & - & - & - & - & - & \multirow[t]{4}{*}{0.396} \\
\hline & Low & 5 & $2.6 \%$ & 2 & $1.1 \%$ & 7 & $3.9 \%$ & \\
\hline & Fair & 72 & $37.9 \%$ & 77 & $43.3 \%$ & 66 & $36.9 \%$ & \\
\hline & High & 113 & $59.5 \%$ & 99 & $55.6 \%$ & 106 & $59.2 \%$ & \\
\hline \multirow{4}{*}{$\begin{array}{c}\text { Interpersonal } \\
\text { Relations }\end{array}$} & Poor & - & - & - & - & - & - & \multirow[t]{4}{*}{0.336} \\
\hline & Low & 9 & $4.7 \%$ & 7 & $3.9 \%$ & 15 & $8.4 \%$ & \\
\hline & Fair & 87 & $45.8 \%$ & 90 & $50.6 \%$ & 84 & $46.9 \%$ & \\
\hline & High & 94 & $49.5 \%$ & 81 & $45.5 \%$ & 80 & $44.7 \%$ & \\
\hline \multirow{4}{*}{$\begin{array}{c}\text { Health } \\
\text { Responsibility }\end{array}$} & Poor & - & - & - & - & - & - & \multirow[t]{4}{*}{0.823} \\
\hline & Low & 12 & $6.7 \%$ & 9 & $5.5 \%$ & 7 & $4.6 \%$ & \\
\hline & Fair & 69 & $38.5 \%$ & 57 & $34.5 \%$ & 55 & $36.2 \%$ & \\
\hline & High & 98 & $54.7 \%$ & 99 & $60.0 \%$ & 90 & $59.2 \%$ & \\
\hline
\end{tabular}

$\mathrm{WKU}=$ Wolkite University, DBU = Debre Brahan University WSU = Wolaita Sodo University

Table. 3 Independent T-test of health-promoting lifestyle profile 2 by gender

\begin{tabular}{|c|c|c|c|c|}
\hline & Gender & $\mathrm{N}$ & Mean \pm Std.Dev & p-value \\
\hline \multirow{2}{*}{ Physical Activity } & Male & 448 & $2.2738 \pm 0.61239$ & \multirow{2}{*}{0.009} \\
\hline & Female & 99 & $2.0960 \pm 0.58326$ & \\
\hline \multirow{2}{*}{ Nutrition } & Male & 448 & $2.3473 \pm 0.44979$ & \multirow{2}{*}{0.003} \\
\hline & Female & 99 & $2.4958 \pm 0.44803$ & \\
\hline \multirow{2}{*}{ Stress Management } & Male & 448 & $3.0402 \pm 0.50307$ & \multirow{2}{*}{0.553} \\
\hline & Female & 99 & $3.0735 \pm 0.51256$ & \\
\hline \multirow{2}{*}{ Interpersonal Relations } & Male & 448 & $2.8119 \pm 0.61777$ & \multirow{2}{*}{0.788} \\
\hline & Female & 99 & $2.8308 \pm 0.69329$ & \\
\hline \multirow{2}{*}{ Health Responsibility } & Male & 448 & $3.0781 \pm 0.74356$ & \multirow{2}{*}{0.495} \\
\hline & Female & 99 & $3.1338 \pm 0.69281$ & \\
\hline \multirow[t]{2}{*}{ Spiritual Growth } & Male & 448 & $2.6486 \pm 0.3233$ & \multirow{2}{*}{0.407} \\
\hline & Female & 99 & $2.6782 \pm 0.31242$ & \\
\hline
\end{tabular}


Table 4. Mean, standard deviation and ANOVA significance level of subscales of health-promoting lifestyle, separated by University.

\begin{tabular}{|c|c|c|c|c|}
\hline & Universities & $\mathrm{N}$ & Mean \pm Std.Dev & p-value \\
\hline \multirow{4}{*}{$\begin{array}{l}\text { Physical } \\
\text { Activity }\end{array}$} & Wolkite University & 190 & $2.1798 \pm 0.56627$ & \multirow{4}{*}{0.138} \\
\hline & Debre Brahan University & 178 & $2.2425 \pm 0.59240$ & \\
\hline & Wolaita Sodo University & 179 & $2.3063 \pm 0.66764$ & \\
\hline & Total & 547 & $2.2416 \pm 0.61056$ & \\
\hline \multirow{4}{*}{ Nutrition } & Wolkite University & 190 & $2.3544 \pm 0.45820$ & \multirow{4}{*}{0.719} \\
\hline & Debre Brahan University & 178 & $2.3769 \pm 0.46235$ & \\
\hline & Wolaita Sodo University & 179 & $2.3925 \pm 0.43860$ & \\
\hline & Total & 547 & $2.3742 \pm 0.45270$ & \\
\hline \multirow{4}{*}{ Stress Management } & Wolkite University & 190 & $3.0722 \pm 0.52098$ & \multirow{4}{*}{0.457} \\
\hline & Debre Brahan University & 178 & $3.0562 \pm 0.46945$ & \\
\hline & Wolaita Sodo University & 179 & $3.0086 \pm 0.52069$ & \\
\hline & Total & 547 & $3.0462 \pm 0.50449$ & \\
\hline \multirow{4}{*}{$\begin{array}{l}\text { Interpersonal } \\
\text { Relations }\end{array}$} & Wolkite University & 190 & $2.8316 \pm 0.63354$ & \multirow{4}{*}{0.811} \\
\hline & Debre Brahan University & 178 & $2.7907 \pm 0.57560$ & \\
\hline & Wolaita Sodo University & 179 & $2.8226 \pm 0.68309$ & \\
\hline & Total & 547 & $2.8154 \pm 0.63148$ & \\
\hline \multirow{4}{*}{$\begin{array}{l}\text { Health } \\
\text { Responsibility }\end{array}$} & Wolkite University & 190 & $3.0039 \pm 0.71570$ & \multirow{4}{*}{0.079} \\
\hline & Debre Brahan University & 178 & $3.0899 \pm 0.71480$ & \\
\hline & Wolaita Sodo University & 179 & $3.1760 \pm 0.76605$ & \\
\hline & Total & 547 & $3.0882 \pm 0.73434$ & \\
\hline \multirow{4}{*}{ Spiritual Growth } & Wolkite University & 190 & $2.6286 \pm 0.3043$ & \multirow{4}{*}{0.187} \\
\hline & Debre Brahan University & 178 & $2.6886 \pm 0.30902$ & \\
\hline & Wolaita Sodo University & 179 & $2.6464 \pm 0.34838$ & \\
\hline & Total & 547 & $2.654 \pm 0.32128$ & \\
\hline
\end{tabular}

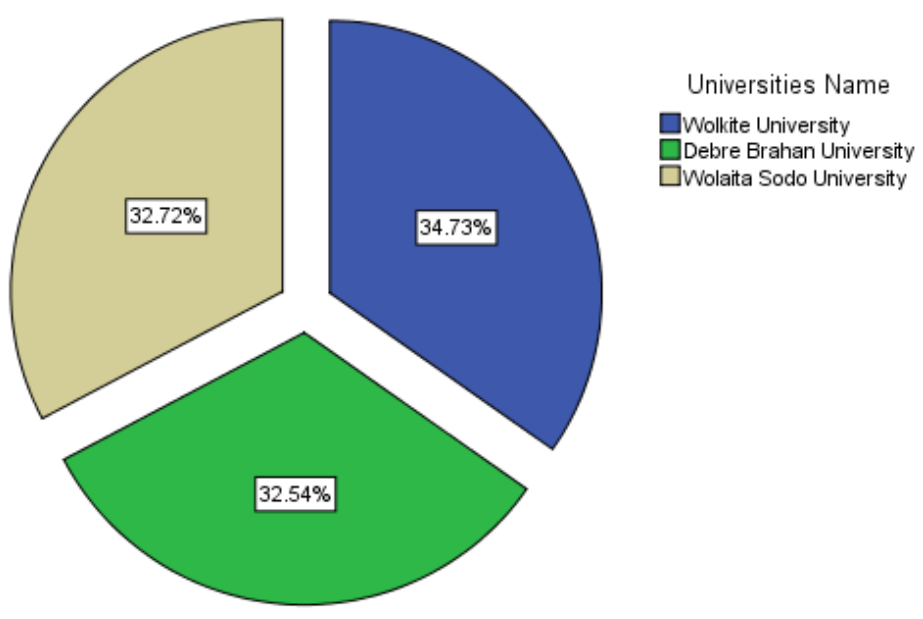

Fig..1 Pie chart of respondents by their university 